\title{
DA LEITURA DE UMA PICTURE À IMAGEM DE UMA TEORIA: METAIMAGENS DA REDE MINAS
}

\section{FROM THE READING OF A PICTURE TO THE THEORY OF AN IMAGE: METAIMAGES FROM REDE MINAS}

\author{
Simone Maria Rocha*, Olívia Érika Alves Resende**
}

\begin{abstract}
Resumo
$\mathrm{O}$ artigo parte da abordagem teórico-metodológica dos estudos de cultura visual com o objetivo de analisar a composição imagem/texto que forma a picture da seção de "Cultura" do site da Rede Minas de Televisão, emissora pública e aberta, vinculada à Secretaria de Estado de Cultura de Minas Gerais. Buscamos perceber elementos verbos-visuais que a picture parece mostrar ou esconder quanto à programação classificada pela emissora como "cultural”. Neste percurso investigativo, deparamo-nos com metaimagens que tanto instauram questionamentos sobre estruturas conceituais e políticas que sustentam uma determinada concepção de cultura, quanto nos levam a refletir e imaginar um perfil de audiência com o qual a emissora pública pretende comunicar-se. Ao experimentar esse gesto de "dar imagem à teoria", concluímos pelas dificuldades e negligências de TVs públicas quando se trata de assumir as complexidades das culturas populares latino-americanas.
\end{abstract}

Palavras-chave: Metaimagem. Televisão pública. Rede Minas. Estudos visuais. Cultura.

\begin{abstract}
This paper adopts the theoretical-methodological approach of visual culture studies, with the objective of analyzing the image/text composition that forms the picture of the "Culture" section of Rede Minas de Televisão website, a public broadcaster linked to the cultural department of the Government of the State of Minas Gerais. We seek to perceive verbal-visual elements that the referred picture seems to show or to hide about the programming classified by the broadcaster as "cultural". In this investigative process, we are confronted with metaimages that present questions about conceptual and political structures that support a particular conception of culture, and that lead us to reflect and imagine a profile of the audience with which the public broadcaster intends to communicate. In experiencing this gesture of "imagining the theory," we conclude by noting the difficulties and neglects of public TVs when it comes to taking on the complexities of Latin American popular cultures.
\end{abstract}

Keywords: Metaimage. Public television. Rede Minas. Visual studies. Culture.

\footnotetext{
* Professora permanente do PPGCOM/UFMG; coordenadora do Grupo de Pesquisa COMCULT; Doutora em Comunicação e Cultura pela UFRJ. E-mail: rochasimonemaria@gmail.com

** Mestre pelo PPGCOM/UFMG; integrante do Grupo de Pesquisa COMCULT. E-mail:

oliviaeresende@gmail.com
} 


\section{Datas de submissão e aprovação do artigo}

Submissão: $28 / 8 / 2018$

Aceito: $21 / 6 / 2019$

Os frequentes debates e ataques ${ }^{1}$ pelos quais passa a TV pública brasileira desencadeiam reflexões em torno da relevância e da gestão da comunicação pública no cenário televisivo, em torno do perfil de programação oferecida e dos desafios em dialogar com as audiências (MAURÍCIO, 2008; RAMOS e outros, 2016). Neste cenário, nos questionamos sobre o papel exercido pela Rede Minas de Televisão ${ }^{2}$, emissora pública e aberta vinculada à Secretaria de Estado de Cultura de Minas Gerais e que tem como missão "[e]nriquecer a vida das pessoas, por meio de serviços, produção, distribuição e exibição de conteúdos audiovisuais informativos, culturais e educativos" (MISSÃO, 2017, negrito presente no texto original). Especificamente, refletimos neste artigo sobre a oferta de programação encontrada na seção de "Cultura" do sítio eletrônico da Rede Minas, a fim de perceber tanto o que sustenta a concepção de cultura proposta pela emissora quanto a abrangência da programação apresentada no site, sendo este composto por imagens e textos.

Tal proposta toma por base a abordagem teórico-metodológica dos estudos de cultura visual, cujo objetivo é analisar a composição imagem/texto que forma uma picture, a fim de perceber elementos verbos-visuais que esta elege e torna visível. Partimos da distinção entre image e picture tal como operada por W.J.T. Mithchell (2009, p.6) que concebe a primeira como imagem descorporeizada e a segunda como a imagem corporeizada, encarnada em um meio ou em um suporte. No livro ¿Qué quieren la imágenes?, o pesquisador resume essa distinção em uma célebre frase: "[v]ocê pode pendurar uma picture, mas você não pode pendurar uma imagem" (MITCHELL, 2017 , p. 117, tradução nossa) ${ }^{3}$.

Para Mitchell $(2009,2017)$ a picture é uma instância dialética que devolve o olhar ao observador e o questiona. Assim, buscamos adotar o gesto sugerido pelo pesquisador de interpelar e de deixarmos ser interpeladas pela representação visual, de acatar a dimensão excessiva desta frente a discursos previamente moldados e de completar uma trajetória de investigação que parta da própria picture, de modo a produzir o que Mitchell entende por "dar imagem à teoria".

Ao traçarmos esse percurso investigativo para analisar a seção de "Cultura" da Rede Minas, deparamo-nos com demandas impostas pelo composto

\footnotetext{
${ }^{1}$ Destacamos as investidas realizadas ainda na gestão do então presidente Michel Temer - que, dentre outras iniciativas, encerrou as atividades do Conselho Curador da Empresa Brasil de Comunicações (BRASIL, Medida Provisória $n^{\circ} 744$, de 2016) - e a promessa de campanha de Jair Bolsonaro em privatizar ou extinguir a TV Brasil (SOUZA, 2018).

2 Rede Minas é o nome fantasia da emissora que, juridicamente, é denominada Fundação TV Minas Cultural e Educativa, ou apenas TV Minas (BRASIL, Lei $\mathrm{n}^{\circ} 11.179$, de 1993).

${ }^{3}$ Traduzido do original: "Puedes colgar una picture pero no puedes colgar una imagen".
} 
imagem/texto que forma a picture. Esta nos oferece metaimagens que instauram questionamentos, não apenas sobre o conteúdo cultural veiculado, mas sobre a concepção de cultura que subjaz a programação oferecida pela emissora pública e sobre o perfil de audiência para o qual a Rede Minas dirige suas estratégias de comunicabilidade.

A partir dessa dupla interpelação instaurada pela picture, somos conduzidos a aprofundar nas determinações históricas, sociais e politicas da experiência visual, a notar que entre a imagem e o texto há uma série de cruzamentos de estruturas sociais e de poder próprias da sociedade em que a TV está inserida. Tal encaminhamento nos leva a refletir sobre as dificuldades e negligências da comunicação pública para assumir as complexidades das culturas populares no contexto brasileiro e latino-americano, tal como observam Omár Rincón e Martín Bezerra (2016).

\section{AS IMAGENS FALAM POR SI?}

Imagem 1: parte superior do layout da seção "Cultura" do site da Rede Minas

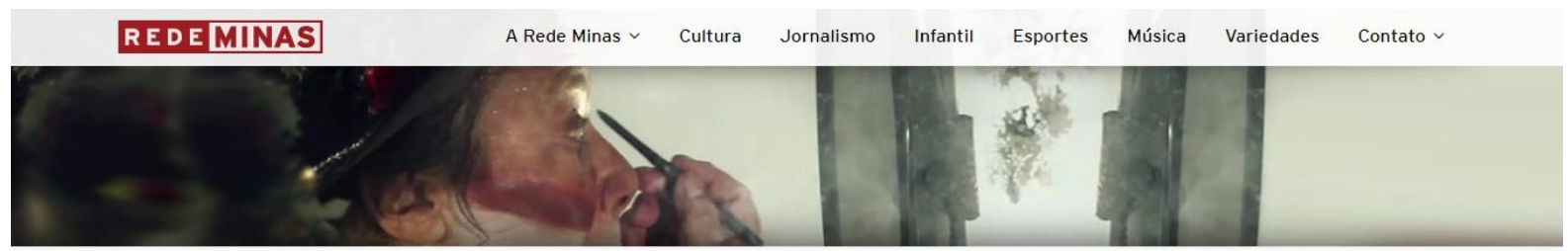

Início > Cultura

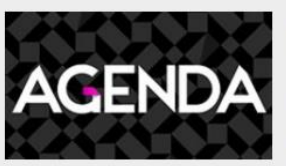

Agenda: Uma revista eletrônica cultural com viés estético e crítico sobre teatro, cinema, artes plásticas, música, literatura e outras manifestações artísticas. No ar desde 1987, é um dos programas mais antigos da Rede Minas.

Apresentação: Mariana Lima

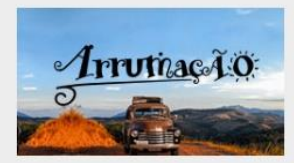

Arrumação: Música, dança, teatro, poesia, prosa, folclore, tradições

populares, noticia boa e bom-humor. No palco, as diversas geraçôes

preservam as raizes da cultura.

Apresentação: Saulo Laranjeira

Fonte: Print screen em execução no navegador Google Chrome

Suponhamos que você acesse o sítio eletrônico da Rede Minas e se depare com o hiperlink da seção "Cultura"4: o que você consegue ver? Na extremidade da parte superior da tela, uma faixa horizontal com a marca da Rede Minas é seguida por seções informativas: duas delas com dados institucionais e seis outras que organizam o conteúdo da programação da emissora pública, cultural e educativa

\footnotetext{
${ }^{4}$ Disponível em: http://redeminas.tv/cultura/.
} 
mineira: "Cultura”, “Jornalismo”, “Infantil”, “Esporte”, “Música”, “Variedades”. Entre este índice geral e a ordenação vertical dos programas da seção de cultura, está exposta uma composição imagética que deixa visível apenas uma fração do rosto de uma pessoa que se pinta em frente a um espelho. Um olhar mais detido neste espelho mostra-nos que se trata de retrovisores que se encontram em posições distintas.

Traços brancos e vermelhos colorem aquele rosto da orelha até a boca. Gotículas de suor se concentram na testa. A mão ensaia o movimento do próximo contorno. De início, imaginamos um índio, ou índia, em um momento de preparação para um ritual. Um pouco mais de concentração e a figura nos revela outra possível imagem: a de um(a) artista de teatro em produção. Diante de tal instabilidade da imagem, seja uma ou outra representação, ou nenhuma delas, o que não está visível para nós é o reflexo da pessoa naqueles espelhos.

A situação descrita é relevante na medida em que abre o espaço de cena para experiências-chave no campo dos chamados estudos de cultura visual: a visão e a visualidade, ambas imersas na vida cotidiana, cujas práticas e processos envolvem as relações entre a biologia, as ciências sociais e as culturas (MITCHELL, 2005; FOSTER, 1988; JAY, 2002; KNAUSS, 2006; SÉRVIO, 2014; ROCHA, 2017). Conquanto Foster (1988) esclareça que há distinção entre essas dimensões - a visão seria, pois, a percepção visual como operação física, e a visualidade seria a percepção visual como fato social - afirma este autor que não são opostas, pois se manifestam numa relação dialética: "a visão é também social e histórica, e a visualidade envolve corpo e psique” (FOSTER, 1988, p. IX):

\begin{abstract}
aqui, a diferença entre os termos assinala uma diferença no interior do visual - entre os mecanismos da visão e suas técnicas históricas, entre o dado da visão e suas determinações discursivas - uma diferença, muitas diferenças, entre de que modo vemos, como somos capazes, autorizados ou levados a ver, e como vemos esse ver ou o não-visto dentro dele. (FOSTER, 1988, p. IX, tradução nossa) $)^{5}$.
\end{abstract}

Essa abertura dialética é o gesto central e por suas vias torna possível compreender que a visão e a visualidade estão relacionadas à experiência visual ou à percepção visual, por meio de competências biológicas e fisiológicas da visão (agenciando aspectos óticos e psíquicos) e da construção social e histórica da visão (a capacidade de produzir subjetividades, discursos, textualidades, normatividades, etc.) no âmbito da cultura.

${ }^{5}$ Traduzido do original: "Although vision suggests sight as a physical operation, and visuality sight as a social fact, the two are not opposed as nature to culture: vision is social and historical too, and visuality involves the body and the psyche. Yet neither are they identical: here, the difference between the terms signals a difference within the visual-between the mechanism of sight and its historical techniques, between the datum of vision and its discursive determinations-a difference, many differences, among how we see, how we are able, allowed, or made to see, and how we see this seeing or the unseen therein". 
Pablo Petit Passos Sérvio (2014) salienta que parte desse processamento da experiência visual que acontece no cérebro seriam a percepção seletiva e os neurônios-espelho. Sérvio (2014, p. 198) explica que, no primeiro caso, o cérebro humano não processa todas as informações visuais captadas pelos olhos, mas as seleciona a partir do que se presume ser mais importante, ao passo que, também, enxergamos com a atenção direcionada para certas informações, enquanto desprezamos outras. Porém, Sérvio (2014, p. 199) ${ }^{6}$ alerta que a percepção seletiva tem a sua explicação fisiológica, mas, também, pode ser compreendida pela “dimensão cultural do olhar, dimensão histórica e contextual” - isto é, a visualidade - que, segundo o autor, "em grande medida, predispõe a focar nossas atenções para algumas coisas, eventos ou pessoas". Por essa via, concordamos com Mitchell (2009, p. 11, tradução nossa $)^{7}$ de que as "as tensões entre as representações visuais e verbais não podem ser separadas das lutas que ocorrem na política cultural e na cultura política”, entendo-as como construções/criações.

De acordo com Mitchell (2005a, p. 343, tradução nossa) ${ }^{8}$, os Estudos Visuais (ou estudos de cultura visual) "encorajam a reflexão sobre as distinções entre arte e não-arte, signos verbais e visuais e as proporções entre diferentes modos sensoriais e semióticos" que perpassam as materialidades simbólicas e visuais (fotografias, esculturas, filmes, programas televisivos, etc.) diversas. Tal perspectiva amplia a abordagem do campo, uma vez que abrange práticas cotidianas de ver e mostrar, especialmente aquelas que consideramos imediatas ou não mediadas. Assim, a construção visual do social e a construção social do visual são interagentes nesse campo dialético.

Tais estudos buscam compreender as mesclas sensoriais e semióticas que perpassam as distintas materialidades, respeitando as suas peculiaridades como práticas sociais, culturais e políticas, uma vez que, como defende Mitchell (2005b, p. 20, grifos do autor; tradução nossa) ${ }^{9}$, não existem meios puramente visuais: “todos os meios são mistos. Isto é, a própria noção de meio e mediação implica por si só uma mescla de elementos sensoriais, perceptivos e semióticos". Assim, o que existem são mesclas que ocorrem de diferentes modos e em diferentes proporções, porque

\footnotetext{
${ }^{6}$ Como exemplo, Sérvio (2014) cita o trabalho de Fernando Braga da Costa (2004) que descreve o caso dos garis como "homens invisíveis": homens e mulheres que quando vestem o uniforme relatam que não são mais vistos. Este é, também, um exemplo de como as roupas tornaram-se fundamentais para a nossa sociabilização, podendo nos destacar ou, até mesmo, apagar. Para pensar o caso dos Garis seria, portanto, necessário não se satisfazer simplesmente com a ideia de que a percepção é seletiva. É preciso compreender porque em tal contexto certas roupas levam certos indivíduos à invisibilidade (SÉRVIO, 2014, p. 199).

7 Traduzido do original: "las tensiones entre las representaciones visuales y las verbales no pueden desligarse de las luchas que tienen lugar en la política cultural y la cultura política".

${ }^{8}$ Traduzido do original: "Visual culture encourages reflection on the differences between art and nonart, visual and verbal signs, and tile ratios between different sensory and semiotic modes".

9 Traduzido do original: "todos los medios son medios mixtos. Es decir, la propria noción de medio y mediación ya implica de por si una mezcla de elementos sensoriales, perceptivos y semióticos".
} 
[c]omo descreve Raymond Williams, um meio é uma 'prática social material', não uma essência discernível, ditada por alguma materialidade elementar (pintura, pedra, metal) ou pela técnica ou pela tecnologia (MITCHELL, 2005b, p. 20, tradução nossa $)^{10}$.

Por essa perspectiva, há, pois, uma rede complexa que envolve os instrumentais técnicos de produção e reprodução - específicos em cada objeto empírico, por exemplo, a televisão e a internet - as instituições sociais, as formas de figuração do mundo e a presença do observador/espectador. Assim, a visualidade passa a ser objeto de especial atenção, de acordo com Mitchell (2005; 2009), que corresponde às práticas de ver o mundo em que se processam os regimes de visualidade, ou seja, os modos como vemos o que vemos, sob o agenciamento de questões socioculturais, de certa forma, também, impressas nessa experiência.

De acordo com Brea (2005, p. 8-9), no campo dos Estudos Visuais a visualidade é um objeto de estudo compreendido num jogo que se processa entre os operadores (textuais, mentais, imaginários, sensoriais, mnemônicos, midiáticos, técnicos, burocráticos, institucionais) e os interesses de representação (de raça, gênero, classe, diferença cultural, grupos de crenças e afinidades etc.). Assim, para o autor, como também para Mitchell, os atos de ver e de fazer ver - e os modos de ver como vemos - são resultados de uma construção cultural, complexa e híbrida.

Centralmente, o que propõe Mitchell é que se i) assuma o que ele denominou de "virada pictorial" não como a superação da "virada linguística", mas enquanto um gesto de dar imagem à teoria e não teoria à imagem; ii) adote o conceito de visualidade; iii) analise as pictures, ao invés das images; iv) estude a interação entre representações visuais e verbais através do composto imagem/texto.

Ao tratar especificamente das representações visuais, Mitchell $(2009,2017)$ faz uma distinção entre image e picture. Apesar de ambas coexistirem e serem consideradas pelo pesquisador como "um ponto singular de fricção e desassossego que atravessa transversalmente uma grande variedade de campos de investigação intelectual” (MITCHELL, 2009 p. 21, tradução nossa) ${ }^{11}$, o termo image (imagem) é genérico e virtual, abarca objetos físicos e/ou mentais, semelhanças, formas, motivos e articula uma interseção complexa entre o visível e o legível, questionando inclusive a fronteira entre a visão e outros sentidos (MITCHELL, 2017,

${ }^{10}$ Traduzido do original:"Como escribe Raymond Williams, un medio es una 'prática social material', no una esencia discenible dictada por alguna materialidad elemental (pintura, piedra, metal) o por la técnica o la tecnología".

${ }^{11}$ Traduzido do original: “(...) las imágenes (pictures) constituyen un punto singular de fricción y desasosiego que atraviesa transversalmente una gran variedad de campos de investigación intelectual". 
p. 25). O pesquisador sugere, então, o uso do termo picture - que usaremos em inglês, por não encontrarmos um termo correspondente em português - para tratar de uma imagem em seu contexto de aparição, formada por práticas e suportes materiais a partir dos quais uma imagem se mostra, ou seja, da situação de manifestação concreta de uma imagem: "a picture é a imagem mais o suporte; é a aparência da imagem imaterial em um meio material” (MITHELL, 2017, p. 118, tradução nossa $)^{12}$. Uma picture ultrapassa o signo de uma imagem e refere-se à situação completa na qual uma imagem aparece, considerando as suas condições de recepção, isto é, à imbricação da imagem, com o objeto e com o meio ${ }^{13}$.

Tratando o layout da Rede Minas como uma picture, isto é, considerando a imbricação do seu composto verbo-visual, com o suporte em que é veiculada e o contexto cultural em que está inserida, somos levados a questionar e desdobrar as relações entre as imagens e textos que nos são visíveis, além da invisibilidade daquele rosto que procura se ver no espelho mas que não nos mostra seu reflexo.

\section{A METAIMAGEM DA AUDIÊNCIA DA REDE MINAS}

Continuando a exploração da seção “Cultura” do sítio eletrônico da Rede Minas, é possível perceber a ordenação vertical dos programas abrigados nesta editoria, acompanhados de textos síntese de cada produção: Agenda, Cinematógrafo, Arrumação, Brasil de Todas as Telas, Conversações e Faixa de cinema. Os textos nos induzem a imaginar que a arte cinematográfica possui relevância dentro do escopo da cultura mineira, uma vez que dois deles - Faixa de Cinema e Cinematógrafo - são exclusivos a essa temática, além de o cinema estar também em meio aos temas listados pelo programa Agenda. Este, de acordo com a descrição da emissora, se trata de uma "uma revista eletrônica cultural sobre teatro, cinema, artes plásticas, literatura” - sendo que a arte literária também aparece como tema principal do Conversações - além de "outras manifestações artísticas de forma aprofundada". Por outro lado, a Rede Minas também promete ao público a inclusão de outra cultura, a, supostamente, popular. Ela nos chega pelo programa Arrumação que vincula a manifestação cultural do povo ao folclore, às tradições, às “raízes da cultura”.

\footnotetext{
12 Traduzido do original: "La picture es la imagen más el soporte; es la apariencia de la imagen inmaterial en um medio material".

${ }^{13}$ A noção de "meio" utilizada por Mitchell (2017) remete a Raymond Williams, para quem que o suporte, ou meio, não é apenas um objeto material na qual a imagem aparece; os meios implicam mediação e, enquanto instituição complexa, acarretam "prácticas materiales que implican tecnologías, habilidades, tradiciones y hábitos. El medio es más que el material y (con permiso de Mcluhan) más que el mensaje, más que simplemente la imagen más su suporte - a menos que entendamos que el 'suporte' es un sistema de suporte".
} 
Imagem 2: Visão ampliada do layout da seção "Cultura" da Rede Minas

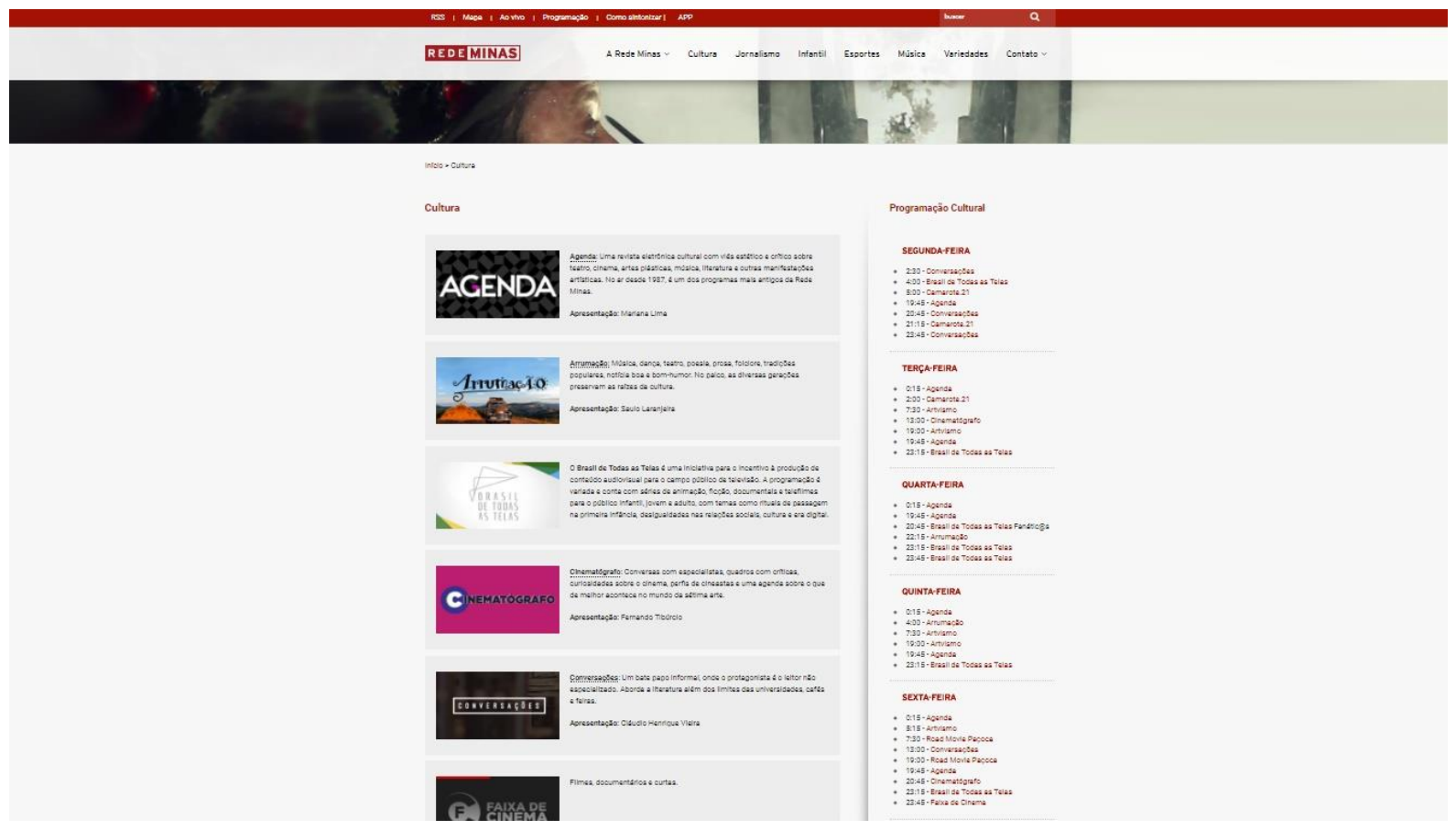

Fonte: Print screen em execução no navegador Google Chrome

Na sequência, deparamo-nos com a programação cultural de outras TVs públicas parceiras: o Artivismo, um programa de "arte independente"; o Camarote.21, que traz as tendências artísticas europeias; e o Sr. Brasil, um programa que se diz muito diverso e só não aborda aquilo "que não seja genuinamente nacional" (SR.BRASIL, 1996-2018).

Qual é a concepção de cultura assumida pela emissora que essa picture agencia? O que sustenta essa divisão entre "arte" e "cultura popular" sob a qual parece estar baseada a "programação cultural da Rede Minas"?

Temos aqui uma visão dicotômica e ingênua de cultura, apesar de comum em nossas sociedades, porque ilustra um velho debate entre românticos e ilustrados (MARTÍN-BARBERO, 2009; STOREY, 2015; CHAUÍ, 1994): ou a cultura é um conjunto de costumes e expressões "autênticos", de um povo "original" que precisa ser resgatado e preservado ou é com "C" maiúsculo, a da arte mais "elevada" que, segundo difusionistas, precisa ser levada às maiorias para que estas possam se tornar cultas. Essa premissa da qual parte a emissora nos é sintetizada na representação visual do índio/artista escolhida para compor o layout da seção e que resiste a uma interpretação estável. 
Imagem 3: detalhes da imagem do índio/artista

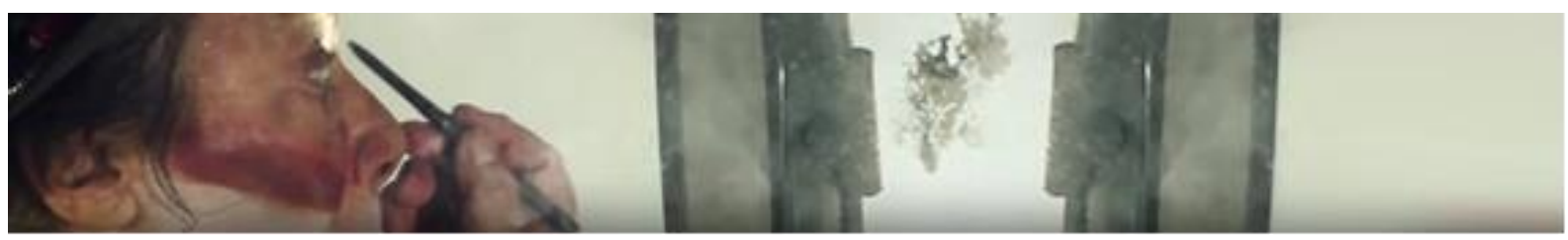

Fonte: Departamento de Marketing da Rede Minas de Televisão

A representação visual que ilustra o todo da seção "Cultura" nos oferece a coexistência de duas distintas imagens, leituras que dialogam justamente com as matrizes culturais identificadas na grade de programação apresentada pela editoria: alta cultura e cultura popular. Por um lado, a imagem do artista de teatro se associa aos programas de cultura que se restringem quase que ao cinema e outras artes tradicionais, como a literatura, por exemplo. Por outro, a imagem do índio vincula-se aos programas Arrumação e Sr. Brasil, das "raízes" culturais e expõe a faceta patrimonialista do Estado que entende a cultura popular apenas como tradição de uma nação, aquilo que seria original, feito pelo povo e para o povo: uma cultura folclórica, com autenticidade e pureza de origem.

Essa autorreferencialidade intrínseca da relação entre as imagens e os textos exemplificam o que Mitchell (2009) compreende como a metaimagem (ou metapicture). De acordo com Mitchell, a metaimagem diz dessa capacidade inerente à representação: “é o lugar onde as imagens se revelam e se 'conhecem', onde refletem sobre as interseções entre a visualidade, a linguagem e a semelhança, onde especulam e teorizam sua própria natureza e história" (MITCHELL, 2009, p. 77, tradução nossa) ${ }^{14}$. Em outras palavras, as metaimagens “olham as imagens 'enquanto' teoria, como reflexões de segunda ordem sobre as práticas de representação visual; perguntam-se o que as imagens nos dizem quando se teorizam (ou se representam) a si mesmas"; por isso o pesquisador propõe que examinemos as relações entre as imagens e o discurso, procurando "substituir uma teoria, fundamentalmente binária, sobre essa relação, com una imagem dialética, a figura da “imagentexto'” (MITCHELL, 2009, p. 18; tradução nossa) ${ }^{15}$.

Mitchell entende que a metaimagem resiste a uma "domesticação", a uma interpretação e a um estatuto cultural fixo. Dialética, a metaimagem é também "selvagem" e se forma por distintos efeitos estruturais - por exemplo, mudança

14 Traduzido do original: “(...) es el lugar donde las imágenes se revelan y se 'conocen', donde reflexionan sobre las intersecciones entre la visualidad, el lenguaje y la similitud, donde especulan y teorizan sobre su propia naturaleza e historia".

15 Traduzido do original: “(...) las 'metaimágenes' (metapictures) miran a las imágenes 'en tanto que' teoría, como reflexiones de segundo orden sobre las prácticas de representación visual; se preguntan qué es lo que las imágenes nos dicen cuando se teorizan (o se representan) a sí mismas. 'Más allá de la comparación' examina la relación entre las imágenes y el discurso y trata de reemplazar una teoría, fundamentalmente binaria, sobre esa relación, con una imagen dialéctica, la figura de la 'imagentexto'”. 
entre figura e fundo, alteração de aspecto e paradoxos visuais expressos - em conjunto com um campo cultural mais amplo. Por isso o pesquisador ressalta que, apesar de a metaimagem ser uma característica inerente a qualquer representação visual, nem toda imagem é uma metaimagem, e a autorreferência não é uma característica exclusivamente formal e intrínseca ao composto imagético, ou seja, a metaimagem apresenta-se também como "um elemento funcional e pragmático, uma questão de uso e contexto" (MITCHELL, 2009, p. 57, tradução nossa) ${ }^{16}$.

A abordagem das interações verbais e visuais de uma picture, através do composto imagem/texto, está no cerne da proposta de Mitchell (1986, 2005, 2009) - amparada pela heterogeneidade dos meios. Para evidenciar o cisma ou a problemática na representação, Mitchell (2009) opta pela barra diagonal (“/”) para designar as relações entre o visual e o verbal bem como para evidenciar o espaço onde se desenrola o jogo do verbal e do visual, na materialidade mesma da representação. É nesta fissura da imagem/texto que a visualidade escapa ou, como adverte Mitchell, é possível "demonstrar o que não pode ser desenhado ou legível, a fissura da própria representação, as bandas, as camadas e as falhas do discurso, o espaço em branco entre o texto e a imagem" (MITCHELL, 2009, p. 67-68, tradução nossa) ${ }^{17}$.

Desta forma, quando a perspectiva conflitante do índio/artista coincide com as imagens sugeridas pelas descrições indicativas de cada programa cultural da Rede Minas, ocorre uma espécie de uma autorreferencialidade intrínseca da relação imagem/texto da picture. Além disso, saber que a persona da foto trata-se de Teuda Bara, artista do Grupo Galpão, companhia mineira de teatro, não impede ou retira a instabilidade da picture, que, ao final, indica que as duas perspectivas conflitantes não se reduzem nem a uma nem a outra, porque elas se chocam com dois espelhos vazios que não refletem nenhuma das imagens em questão.

Surge, portanto, uma segunda metaimagem que nos interpela sobre a audiência da emissora: assim como o índio/artista que se olha no espelho sem ver seu reflexo, não seria a Rede Minas um espelho daquele telespectador que busca naqueles programas uma imagem de si próprio? Esta questão nos leva a outra: qual é o perfil de audiência para o qual a emissora dirige suas estratégias de comunicabilidade?

Com base em Deleuze, Mitchell diz que a imagem se forma junto com o desejo, sendo este um processo que é interrompido e fixado somente pela figura do prazer que participa da constituição do campo de imanência da picture, campo este formado pela materialidade da imagem, pelo suporte desta e pela situação em

${ }^{16}$ Traduzido do original: “(...)la autorreferencia de la imagen no es una característica exclusivamente formal e interna que distinga a unas imágenes de otras, sino un elemento funcional y pragmático, una cuestión de uso y contexto".

17 Traduzido do original: "demostrar lo que no puede ser dibujado o hecho legible, la fisura de la representación misma, las bandas, capas y líneas de falla del discurso, el espacio en blanco entre el texto y la imagen". 
que esta é observada. A vida da imagem está, portanto, condicionada à complexa relação dialética, social e conversacional que a imagem estabelece com o seu observador (MITCHELL, 2017, p. 142). Assim, nós projetamos nossos desejos sobre a imagem e eles tomam forma quando se projetam de volta para nós, fazendo-nos demandas. Desse modo, poderíamos imaginar que a figura dialética do índio/artista interpela o seu espectador, isto é, ela "retribui" o olhar daquele que observa a seção "Cultura" da emissora e torna o sujeito um objeto em observação. Para Mitchell,

se a imagem multiestável sempre pergunta "O que sou eu?" ou "Como eu me vejo?", a resposta depende de que o espectador faça a si mesmo as mesmas perguntas. Essas perguntas e essas respostas, o diálogo do observador com sua metaimagem, não ocorrem em um terreno incorpóreo, fora da história, mas estão inscritas em discursos, disciplinas e regimes de conhecimento específicos. (...) Talvez o mais notável seja a sua capacidade de se mover através das fronteiras de discursos populares $\mathrm{e}$ profissionais. A metaimagem é uma peça de aparato cultural móvel, que pode desempenhar um papel secundário como uma ilustração ou um papel primário como um tipo de imagem de resumo, o que chamei de "hiperícone" que encapsula toda uma episteme, uma teoria do conhecimento (MITCHELL, 2009, p. 50, tradução nossa) ${ }^{18}$.

Neste caminho de interpretação poderíamos dizer que a ausência dos reflexos dos espelhos da imagem torna visível a invisibilidade da multiplicidade de rostos da nossa cultura. Desta forma, a escolha de uma ilustração que, a princípio, poderia nos passar despercebida, como um complemento ao texto, um recurso decorativo para a seção do site, transforma-se em imagem de uma teoria, o locus de conflito que adentra o espaço do jogo imagem/texto - quer este jogo seja entendido como uma reiteração ou como uma lacuna ou fissura na representação. $E$, para o autor, é exatamente no jogo entre o visual e o verbal que se dá o encontro, que se instaura a tensão e, também, a fissura por onde escorregam as matrizes culturais, o social, a história. Nas palavras de Mitchell (2009, p. 96, tradução nossa) ${ }^{19}$ : “imagem/texto não é nem um método nem uma garantia de

18 Traduzido do original: "Si la imagen multiestable siempre pregunta «¿Qué soy?» o «¿Cómo (se) me ve?», la respuesta depende de que el espectador se haga las mismas preguntas. Estas preguntas y estas respuestas, el diálogo del observador con su metaimagen, no ocurren en un terreno incorpóreo al margen de la historia, sino que están inscritas en discursos, disciplinas y regímenes de conocimiento específicos. (...) Quizá lo más notable sea su capacidad de moverse a través de las fronteras de discursos populares y profesionales. La metaimagen es una pieza de aparato cultural móvil, que puede desempeñar un papel secundario como ilustración o un papel primario como una especie de imagen sumarial, lo que yo he llamado un 'hipericono' que encapsula todo un epistema, una teoría del conocimiento".

19 Traduzido do original: "La imagen/texto no es ni um método ni una garantía de descubrimientos históricos; se parece más a una apertura en la representación, un lugar donde la historia podría colarse por las grietas". 
descobertas históricas; é mais como uma abertura na representação, um lugar onde a história poderia escorregar pelas rachaduras".

Não sendo exatamente um método, perscrutar imagem/texto é mais um gesto proposto por Mitchell que nos sugere considerar a representação em si como o melhor lugar para indagar sobre a heterogeneidade que ela comporta. É por isso que o autor parte da materialidade que estrutura o composto imagem/texto e não de uma teoria que a pressupõe e modela.

Por isso, procedemos à consideração da picture proposta no layout da seção “Cultura" para adentrar nos entrelaçamentos da imagem com o texto disposto no portal e notar que entre a imagem e o texto há uma série de cruzamentos de estruturas sociais e de poder - uma zona em branco que diz do contexto e das determinações históricas e culturais dessa experiência visual; de acordo com Mitchell (2009, p. 68-69), a partir de Foucault, seria possível descrever a identidade da dialética verbo-visual como uma chave da relação entre a teoria e a história. Em outras palavras, na composição imagem/texto está a fissura/lacuna do social e do histórico.

A fissura das metaimagens apresentadas pela Rede Minas faz entrever não apenas sobre a concepção de cultura que alimenta o fazer televisivo do canal que orientas as ações do que incluir e mostrar e do que deixar invisibilizado, mas, também, um saber sobre as estruturas sociais e/ou matrizes culturais, políticas e institucionais próprias da sociedade em que a TV está inserida: por que os programas religiosos, os futebolísticos e os de moda e arte, por exemplo, não são exibidos dentro da seção de cultura? Onde está a cultura popular, não a "autêntica" e erudita apresentada pela programação da Rede Minas, mas aquela cultura popular massiva, urbana, híbrida (CANCLINI, 1997, MARTíN-BARBERO, 2004, 2002, 2009), constitutiva dos grandes centros urbanos brasileiros e que não se faz visível naquela picture? Em que medida podemos relacionar as invisibilidades identificadas na picture ao perfil da audiência com a qual a emissora pretende se comunicar?

\section{DAS ESTRUTURAS SOCIAIS E POLÍTICAS DA PICTURE}

Acreditamos que esse ato político sobre o que tornar visível e o que deixar invisibilizado nas decisões de programação da Rede Minas pode sugerir uma limitação que não ocorre apenas na TV pública mineira. No Brasil e na América Latina, a comunicação pública é fonte de interrogações para profissionais do ramo e especialistas no assunto que, dentre muitos desafios, tentam entender qual seria o público das TVs públicas e qual o modelo de gestão ideal para essas emissoras ${ }^{20}$.

\footnotetext{
${ }^{20}$ No caso da emissora mineira, não há pesquisas para medição de audiência dos programas transmitidos pela TV. A Rede Minas tem feito esse tipo de monitoramento de audiência por meio do consumo do conteúdo veiculado em suas redes sociais (Facebook, Youtube, Instagram e
} 
Para pesquisadores como Omár Rincón e Martín Bezerra (2016), a incapacidade de dialogar com as maiorias é uma dificuldade geral, porque

o popular é algo que não agrada nossas elites - nem de direita nem de esquerda. Por isso, elas creem que a função da televisão pública é educar culturalmente os bárbaros. E está aí a causa do fracasso do projeto das tevês públicas e sua baixa incidência cultural (RINCÓN, 2016, p. 202-203).

Seguindo este esquema, a programação de emissoras públicas é planejada para se diferenciar daquilo que seria próprio de uma cultura comercial, produzida massivamente. Essa conduta das TVs está respaldada pelos indicativos da Lei ${ }^{\circ}$ 11.652, de 7 de abril de 2008, que rege as televisões públicas no Brasil. Dentre as finalidades da programação, as emissoras devem, de acordo com o seu Art. $3^{\circ}$,
a) oferecer mecanismos para debate público acerca de temas de relevância nacional e internacional; b) desenvolver a consciência crítica do cidadão, mediante programação educativa, artística, cultural, informativa, científica e promotora de cidadania; c) fomentar a construção da cidadania, a consolidação da democracia e a participação na sociedade, garantindo o direito à informação, à livre expressão do pensamento, à criação e à comunicação; d) buscar excelência em conteúdos e linguagens e desenvolver formatos criativos e inovadores, constituindo-se em centro de inovação e formação de talentos; e) direcionar sua produção e programação pelas finalidades educativas, artísticas, culturais, informativas, científicas e promotoras da cidadania, sem com isso retirar seu caráter competitivo na busca do interesse do maior número de ouvintes ou telespectadores (BRASIL, lei 11.652 de 2008, grifos nossos).

As TVs públicas, no entanto, parecem construir uma interpretação reducionista da legislação, focando em alguns indicativos e traduzind0-os, muitas vezes, como: “vamos levar a Cultura para o povo!”. Ao partir do pressuposto de que a televisão comercial se resume em mediocridade e inércia intelectual, a comunicação pública seria uma tentativa de emancipação de supostos receptores acríticos. E, voltando à picture da seção de cultura da Rede Minas e o que ela nos diz sobre o perfil de audiência do canal, encontramos ali programas mais especializados, para um público que possui um conhecimento prévio sobre determinados temas, apresentados, muitas vezes, por uma linguagem que não consegue atrair ou se comunicar com as maiorias. Produções que tomam por base "arte independente", as tendências artísticas europeias ou se limitam a aceitar apenas o que é "genuinamente brasileiro".

Ambas as tendências encontradas na picture em questão - a dos românticos e folcloristas com sua concepção populista de cultura, estando esta ligada à

Twitter), como consta no Relatório de Gestão 2015-2018 (RELATÓRIO, 2018). Contudo, os programas da seção "Cultura” não foram observados no Relatório. 
"verdade", à "essência", às raízes do popular que ainda não foi contaminado ou degradado pelo massivo, e a dos ilustrados para os quais a cultura se identifica com a Arte e o massivo é tomado como referência de degradação, alienação e vulgarização, como negação da "verdadeira" Cultura - encobrem a pluralidade do popular na América Latina: isto é, o fato de ele ser um "espaço denso de interações, de intercâmbios e reapropriações” (MARTíN-BARBERO, 2004, p. 140).

A cultura popular é, para Jesús Martín-Barbero (2004, p. 366), uma trama complexa, um emaranhado de interações vivas, da qual fazemos parte, todos nós, qualquer um de nós; um lugar estratégico de ajuntamento e mestiçagem de todas as suas manifestações: religiosas, étnicas, estéticas, políticas, sexuais, assim como um lugar de concessões, negociações, cumplicidades, resistências, de descompasso e descontinuidades.

O valor do popular não reside em sua autenticidade ou em sua beleza, mas sim em sua representatividade sociocultural, em sua capacidade de materializar e de expressar o modo de viver e pensar das classes subalternas, as formas como sobrevivem e as estratégias através das quais filtram, reorganizam o que vem da cultura hegemônica, e o integram e fundem com o que vem da sua memória histórica (MARTíN-BARBERO, 2004, p. 113).

Ao operar com o princípio de que o massivo é "esse outro modo de existência histórica do popular” (SUNKEL, 2016, p.194, tradução nossa) ${ }^{21}$ a televisão comercial consegue se sobrepor à pública, porque é capaz de articular interesses e seduções, por meio da imbricação popular-massivo. Isso porque, a televisão, enquanto mediação, faz parte de um complexo processo comunicativo que não devemos negligenciar: ao mesmo tempo em que ela é meio de comunicação que, como nenhum outro na América Latina, permite o acesso das maiorias a uma "variedade de experiências humanas, de países, de povos e situações", é também um meio que também "des-localiza os saberes, deslegitimando as fronteiras entre a razão e imaginação, saber e informação, natureza e artifício, ciência e arte, saber especializado e experiência profana" (MARTÍN-BARBERO; REY, 2001, p. 18). Assim, a televisão comercial expõe e denuncia o que a televisão pública parece querer disfarçar: essa outra modernidade que vivemos, desviada, heterogênea, mestiça, que está fora do escopo dos relatos de uma pretensa cultura "oficial", porque exprimem em suas televisualidades o que os livros, a Escola e as Artes não conseguem expressar.

Nas palavras de Martín-Barbero (2004, p. 295), a TV é um dispositivo de comunicação "capaz de oferecer formas de resistir ao isolamento das populações marginalizadas, estabelecendo vínculos comuns à maioria da população”. Além

${ }^{21}$ Traduzido do original: “(...) se há intentado, justamente, desmontar ese outo modo de existencia histórica de lo popular a nivel de lo massivo". 
disso, a hegemonia do meio na América Latina está ligada à ausência de espaços de representação política "e à não-representação, no discurso da cultura oficial, da diversidade e das identidades culturais" (MARTíN-BARBERO, 2004, p. 371). Essa carência faz com que o meio massivo seja o lugar em que as pessoas encontram essa representatividade e expressão, onde elas encontram a si mesmas, mesmo que isso seja feito pela TV de forma esquemática, perpassada de interesses econômicos e políticos.

As TVs comerciais estão preocupadas com a educação dos indivíduos, com o crescimento intelectual deles? Cremos que não. Mas, sem público estas emissoras não existiriam, então elas precisam se inserir no regime de visualidade vigente, atentas ao que as pessoas querem ver e mostrar. É uma questão de mediação: há, muitas vezes, desvalorização das complexidades, por um lado, mas há também a expressão de elementos importantes para a cultura popular, de matrizes que constituem os sujeitos.

Encontramos na TV comercial imagens espetaculares, dramáticas, multicoloridas, distorcidas, repetidas, ameaçadoras de tão "perfeitas", redutoras, onipresentes, imagens do "bem" e do "mal", em fluxo, e que sempre se referem a outras imagens e imaginários, porque cada uma delas "é mais que nunca o mundo do híbrido, do sincretismo e da mistura, da confusão de raças e línguas" (GRUZINSKI, 2006, p. 303) que nos forma: “um pouco" indígenas, europeus, negros, brancos, católicos, urbanos e rurais, racionais e apaixonados. É a ausência desses hibridismos que as metaimagens da Rede Minas parecem materializar (e denunciar). A programação cultural "ideal” da emissora carece de mediações, concessões e diálogos com a sociedade. Ao conferir visibilidade a um determinado cinema, a uma determinada literatura, ou a uma determinada música, por exemplo, a Rede Minas leva à invisibilidade a faceta profana, vulgar do mundo popular, o que há de "feio" e "torto" na nossa cultura (MARTíN-BARBERO, 2009). Faz-se assim um canal público, mas restrito, que dialoga com uns poucos letrados.

Essa dificuldade de interlocução identificada é intensificada pelo modelo de gestão que regem as emissoras públicas, como observa Rodrigo Torres: "o uso das concessões de TV como 'moeda de barganha' entre o governo e políticos, prática conhecida como 'coronelismo eletrônico', é fartamente utilizada no país” (TORRES, 2009, p. 31). Martin Bezerra destaca problemas decorrentes das interferências dos governos nos conteúdos exibidos:

a governamentalização dos meios públicos não só contradiz a normativa do setor, como também oferece um cenário de instabilidade na linha editorial quando existe alternância no exercício do poder político (BEZERRA, 2016, p. 165).

Essa alternância de gestão faz com que cada diretor de programação, nomeado para gerenciar uma TV pública, carregue suas “certezas” sobre o que 
seria "bom" para o "povo", desestabilizando o fazer televisivo da emissora. Para Omar Rincón, a gestão estatal se apresenta como um atentado ao que ele chama de "essência da televisão", porque "o processo de contratação de um programa de tevê é o mesmo de construção de uma ponte” (RINCÓN, 2016, p. 203), ou seja, transforma a TV em mais um aparato burocrático do Estado.

Esses são apenas algumas das temáticas que pautam debates, perpassam estudos e que, sobretudo, desafiam pesquisadores e profissionais brasileiros e latino-americanos a aperfeiçoarem a TV pública, ou melhor, “desaperfeiçoá-la”, deixá-la menos elitista e mais popular, menos especializada e mais cotidiana, enfim, mais heterogênea. Neste caminho de ampliação e desenvolvimento de possibilidades e potencialidades comunicativas, eles defendem a importância de as TVs manterem-se independentes ao controle dos governos, de elas articularem uma interlocução mais expressiva com o contexto cultural no qual se inserem (RAMOS e outros, 2016) e do investimento em diferentes formatos e linguagens, a partir das novas tecnologias de informação (BIANCO, 2016; MÉDOLA, 2016). No caso da Rede Minas, a criação de um "conselho aberto" para "ouvir as sugestões do público e selecionar pautas para os programas” (RELATÓRIO, 2018, p. 20), o aperfeiçoamento da transmissão online por meio da contratação de serviço de streaming e o lançamento de um aplicativo para que os usuários possam acompanhar a programação pelo celular são medidas que mostram os esforços da emissora para expandir fronteiras e agregar novos públicos.

Enfatizamos que o caminho adotado neste texto, o de politizar as estruturas editoriais e o perfil das audiências da TV pública, emergiu da experiência visual formada a partir do nosso encontro com a picture da seção "Cultura" do site da Rede Minas. Se para José Luiz Brea (2005), a epistemologia dos estudos visuais deve ser política na medida em que ela conforma atos de ver culturais e politicamente conotados, temos aí um exemplo profícuo do efeito performativo/produção de realidade desse ato: a tela da emissora é um espelho sem rostos porque não consegue refletir a pluralidade daqueles que potencialmente comporiam sua audiência.

\section{REFERÊNCIAS}

BECERRA, Martín. Entrevista: Martín Becerra. Entrevistadora: Gláucia da Silva Mendes Moraes. In: RAMOS, Murilo César et al. Em Defesa da Comunicação Pública. Brasília: FAC-UnB, 2016. 270 p.

BIANCO, Nélia Rodrigues. Entrevista: Nélia Rodrigues Del Biano. Entrevistadoras: Mary Sandra Landim Pinheiro e Jacqueline Lima Dourado. In: RAMOS, Murilo César et al. Em Defesa da Comunicação Pública. Brasília: FAC-UnB, 2016. 270 p. 
BRASIL. Lei $\mathrm{n}^{\circ} 11.652$, de 07 de abril de 2008. Institui os princípios e objetivos dos serviços de radiodifusão pública explorados pelo Poder Executivo ou outorgados a entidades de sua administração indireta. Presidência da República. Disponível em: http://www.planalto.gov.br/ccivil_03/_ato2007-2010/2008/lei//11652.htm Acesso em 01 ago. 2018.

BRASIL. Lei n 11.179, de 1993. Legislação Mineira. Disponível em: <https://www.almg.gov.br/consulte/legislacao/completa/completa-novamin.html>. Acesso em 10 jan. 2019.

BRASIL. Medida Provisória $\mathrm{n}^{\circ}$ 744, de 2016. Disponível em: <https://www.congressonacional.leg.br/materias/medidas-provisorias//mpv/126826>. Acesso em 10 jan. 2019.

BREA, José Luis. Los estudios visuales: por unaepistemología política de la visualidad. In (Ed.). Estudios Visuales: La epistemologia de la visualidad en la era de la globalización. Madrid: Akal Estudios Visuales, 2005.

CANCLINI, Néstor García. Culturas Híbridas - estratégias para entrar e sair da modernidade. São Paulo: EDUSP, 1997.

CHAUÍ, Marilena. Como superar a dicotomia entre conformismo e resistência? In: HERLINGHAUS, H.; WALTER, M. Posmodernidade en la periferia: enfoques latinoamericanos de la nueva teoria cultural. Berlim: Langer, 1994.

CULTURA, Rede Minas. Fundação TV Minas Cultural e Educativa, 2017. Disponível em: <http://redeminas.tv/cultura/>. Acesso em 02 ago. 2018.

FOSTER, H. Preface. In: FOSTER, H. (org.). Vision and visuality. Seattle: Bay Press, 1988.

GRUZINSKI, Serge. A guerra das imagens: de Cristóvão Colombo a Blade Runner (1942 - 2019). São Paulo: Companhia das Letras, 2006. 348 p.

HERLINGHAUS, Hermann; WALTER, Monika. “Modernidad periférica” versus "proyeto de la modernidad"? Experiencias epistemológicas para reformulación de lo 'pos' moderno desde América Latina. In: - Posmodernidade en la periferia: enfoques latinoamericanos de la nueva teoria cultural. Berlim: Langer, 1994.

JAY, Martin. Relativismo Cultural e a virada visual. Tradução de Myriam Ávila, In: Aletria: Revista de Estudos de Literatura, Belo Horizonte, v. 10/11, 2003/2004. Versão original em: Journal of Visual Culture. v. 1. n. 3, dez. 2002.

KNAUSS, Paulo. 0 desafio de fazer História com imagens: arte e cultura visual. ArtCultura, Uberlândia, v. 8, n. 12, p. 97-115, jan.-jun. 2006. 
MARTÍN-BARBERO, Jesús; REY, Germán. Os exercícios do ver: hegemonia audiovisual e ficção televisiva; São Paulo: Editora Senac São Paulo, 2001.

- Oficio de cartógrafo - Travesías latinoamericanas de la comunicación en la cultura. São Paulo: Edições Loyola, 2004.

Dos meios às mediações: comunicação, cultura e hegemonia. Rio de Janeiro: UFRJ, 2009.

MAURÍCIO, Patrícia. Reflexões sobre a TV Pública. Economía Política de las Tecnologías de la Información y Comunicación. Sergipe, vol. 10, n. 3. 2008. Disponível em: <https://seer.ufs.br/index.php/eptic/article/view/200/171>. Acesso em dez. 2018.

MÉDOLA, Ana Silvia Lopes Davi. Entrevista: Ana Silvia Lopes Davi Médola. Estrevistadora: Mayra Fernanda Ferreira. In: RAMOS, Murilo César et al. Em Defesa da Comunicação Pública. Brasília: FAC-UnB, 2016. 270 p.

MISSÃO, visão e valores. Rede Minas. Fundação TV Minas Cultural e Educativa. Disponível em: <http://redeminas.tv/missao-visao-e-valores/>. Acesso em 09 mar. 2018.

MITCHELL, W.J. Thomas. What Do Pictures Want?: The Lives and Loves of Images. Chicago: University of Chicago Press, 2005a.

No existen medios audiovisuales. In Brea, J. L. (Ed.). Estudios Visuales: La epistemologia de la visualidad en la era de la globalización. Madrid: Akal Estudios Visuales, 2005b.

2009.

Teoría de la imagen: ensayos sobre representación. Madri: Ediciones Akal, Qué quieren las imágenes?: una crítica de la cultura visual. Trad. Isabel Mellén. Buenos Aires: Sans Soleil Ediciones, 2017.

RAMOS, Murilo César et al. Em Defesa da Comunicação Pública. Brasília: FAC-UnB, 2016. $270 \mathrm{p}$.

RELATÓRIO de Gestão: 2015-2018. Rede Minas. Fundação TV Minas Cultural e Educativa. 2018. Disponível em: <http://redeminas.tv/wpcontent/uploads/2018/12/relat\%C3\%B3rio_de_gest\%C3\%A3o-v7-web-reduzido.pdf > . Acesso em 01 mar. 2019.

RINCÓN, Omar. Entrevista: Omar Rincón. Entrevistador: Daniel Merli. In: RAMOS, Murilo César et al. Em Defesa da Comunicação Pública. Brasília: FAC-UnB, 2016. $270 \mathrm{p}$. 
ROCHA, SIMONE M. Estudios visuales y estilo televisivo: porque no existen medios puramente visuales. CHASQUI. REVISTA LATINOAMERICANA DA COMUNICACIÓN, v. 135, p. 297-316, 2017.

SÉRVIO, P. Pablo. O que estudam os estudos de cultura visual? Revista Digital do LAV (UFSM), vol. 7, núm. 2, p. 196-215, maio-agosto, 2014.

SOUZA, Gabriel. Bolsonaro diz que vai extinguir ou privatizar a TV Brasil, criada por Lula. Notícias da TV, 29 out. 2018. Uol. Disponível em:

<https://noticiasdatv.uol.com.br/noticia/televisao/jair-bolsonaro-diz-que-vaiextinguir-ou-privatizar-a-tv-brasil-criada-por-lula-23012>. Acesso em 01mar. 2018.

SR.BRASIL. Arte e cultura; Fundação Padre Anchieta, 1996-2018. Disponível em <http://tvcultura.com.br/programas/srbrasil/>. Acesso em 01 ago. 2018.

STOREY, John. Teoria cultural e cultura popular: uma introdução. São Paulo: edições Sesc São Paulo, 2015. - 512 p.

SUNKEL, Guillermo. Razón y Pasión en la prensa popular. Santiago: Ediciones y publicaciones El Buen Aire S.A, 2016. 2a edicion - 204 p.

TORRES, Rodrigo Murtinho de Martinez. Televisão pública no Brasil: estudo preliminar sobre suas múltiplas configurações. Contemporânea. São Paulo, n.12, 2009. Disponível em: <https://www.arca.fiocruz.br/handle/icict/1263>. Acesso em 01 mar. 2019. 